BOGDAN CZYŻEWSKI, POZNAŃ

ORCID: 0000-0002-6040-5523

\title{
WOLNOŚĆ I ŁASKA W NAUCE MARKA EREMITY
}

O Marku Eremicie ${ }^{1}$ mamy niewiele informacji. ${ }^{2}$ Według Nicefora Ksantopulosa miał być uczniem św. Jana Chryzostoma i przełożonym w Ancyrze (dzisiejsza Ankara). ${ }^{3}$ Potem opuścił wspólnotę zakonną i udał się na Pustynię Judzką, gdzie rozpoczął życie pustelnicze. Należy bez wątpienia do najważniejszych teoretyków życia ascetycznego w Kościele starożytnym. ${ }^{4}$ Marek Eremita podejmuje w swoich pismach wiele tematów ascetycznych, m.in. zwraca uwagę mnichów

1 Marek bywa nazywany Markiem Eremitą lub Markiem Mnichem. Niektórzy są zdania, że druga forma jest poprawniejsza, ponieważ w taki sposób nazywany jest w manuskryptach, czyli Markiem Mnichem; zob. A. J a s i e w i c z, Misterium chrztu świętego w nauczaniu ascetycznym św. Marka Mnicha, w: F. D r ą c z k o w $\mathrm{s} \mathrm{k}$ i $\mathrm{i}$ in. (red.), Katechumenat i inicjacja chrześcijańska w Kościele starożytnym, Lublin 2011, s. 207. W niniejszym opracowaniu będziemy używać zarówno jednego, jak i drugiego określenia św. Marka, Marcus Monachus. Pod imieniem Marka Mnicha zostały też niedawno wydane: Opera ascetica: florilegium et sermones tres, wyd. Ph. Roelli, Turnhout 2009, CCG 72. Autor wydanych pism, to jednak inny Marek Mnich, żyjący w XII/XIII w.

2 Wiadomości biograficzne na temat Marka Eremity zob. O. He s s e, Markos Eremites und Symeon von Mesopotamien, Göttingen 1973; J. G r i b o m o n t, Marc le Moine, DSAM 10/1977, kol. 274-283; A. G r i 11 m e i e r, Marco Eremita e l'origenismo, Cristianesimo nella storia 1/1980, s. 9-58; J. G r i b o m o n t, Marc l'Eremite, DECA 2/1990, s. 1535; P. S z c z u r, Marek Eremita, EK 11/2006, kol. 1277; M. S t a r ow i e y s k i, J. M. S z y m u s i k (red.), Nowy słownik wczesnochrześcijańskiego piśmiennictwa, Poznań 2018², s. 690-691.

3 Zob. N ic e phor C a 11 i s t i, Historia ecclesiastica, XIV 30; LIII; LIV, PG 146, 1157; 1252; 1256.

4 Zob. P. S z c z u r, Marek Eremita, kol. 1277. 
na to, by zawsze pamiętali o Bogu, podejmowali walkę z myślami i modlili się bez rozproszeń. ${ }^{5}$

Znamy jedenaście pism św. Marka Eremity: De lege spirituali, De his qui putant se ex operibus iustificari, De paenitentia, De baptismo, Ad Nicolaum praecepta animae salutaria, De temperantia, Disputatio cum quodam causidico, Consultatio intellectus cum sua ipsius anima, De ieiunio, De Melchisedech, Adversus Nestorianos. ${ }^{6}$ $\mathrm{Z}$ całą pewnością w każdym z nich natrafić można na interesujący nas temat, co nie oznacza, że Marek systematycznie omawiał zagadnienie wolności i łaski. Są to raczej wypowiedzi porozrzucane w jego dziełach, okazjonalne, często też do siebie podobne. Dlatego należało dokonać wyboru, by przedstawić najważniejsze teksty odnoszące się do wolności i łaski.

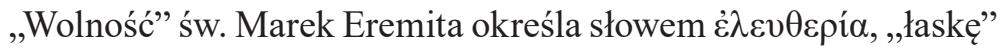
natomiast terminem $\chi \alpha$ pis. W zachowanych pismach tego autora, zarówno w jego ascetycznych i teologicznych refleksjach, jak i w cytowanych przez niego tekstach biblijnych, występują czterdzieści dwa

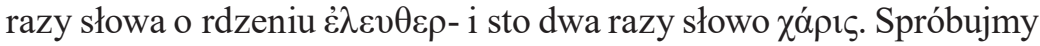
na podstawie wybranych fragmentów poznać opinię naszego autora na temat wolności i łaski.

\section{Wolność}

Marek Eremita w dziele De lege spirituali podkreśla, że chrześcijańska wolność nie polega na beztroskim i swawolnym życiu. Nawiązując do słów św. Pawła, który w Liście do Rzymian stwierdza: „Prawo jest duchowe. A ja jestem cielesny, zaprzedany w niewolę grzechu" (Rz 7,14), mówi, że wolność oznacza posłuszeństwo

5 Zob. J. N a u m o w i c z, Wstęp do: Św. Marek Eremita, w: Filokalia-teksty o modlitwie serca, Tyniec 1998, s. 113.

6 Więcej na temat dzieł Marka Eremity zob. A. J a s i e w i c z, Święty Marek Mnich, O Prawie duchowym, Śląskie Studia Historyczno-Teologiczne 45(2012) nr 2, s. 257-258; M. S t a r o w i e y s k i, J. M. S z y m u s i a k (red.), Nowy słownik wczesnochrześcijańskiego piśmiennictwa, s. 690-691, P. Szczur, Marek Eremita, kol. 1277. 
Chrystusowemu ,prawu wolności”. ${ }^{7}$ Wyjaśnia też, na czym ono polega. Otóż - zdaniem św. Marka Mnicha: „Prawo wolności ['O vó $\mu$ o

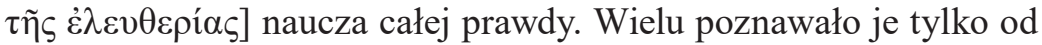
strony teoretycznej, zaś tylko niektórzy rozumieli je właściwie, bowiem starali się wypełniać przykazania". ${ }^{8}$ Autor kładzie zatem główny nacisk na konieczność zachowywania przykazań. Temat ten niezwykle często pojawia się w działach naszego autora. Znajomość prawa wolności nie wystarczy, potrzeba jeszcze wcielić je w praktykę.

Związek wolności z czynem Marek Eremita wyjaśnia jeszcze do-

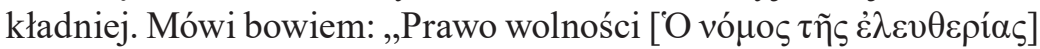
zdobywamy dzięki prawdziwej wiedzy oraz wypełnianiu przykazań, a także przez napełnianie się łaską pochodzącą od naszego Pana Jezusa Chrystusa". ${ }^{9}$ Trzy zatem elementy, według Mnicha, są istotne, by nie powiedzieć niezbędne, do właściwego przeżywania prawa wolności, mianowicie wiedza na jego temat, następnie wspomniane już wcześniej wypełnianie przykazań oraz łaska.

Marek przestrzega jednak, by nie szukać ,istoty tego prawa w zdobywaniu doskonałości dzięki ludzkim cnotom, bowiem doskonałości w nich nie znajdziesz. Prawdziwa doskonałość bowiem ukryta jest w krzyżu Chrystusa". ${ }^{10}$ Co to oznacza? Autor dostrzega głęboki związek między prawem wolności i łaską. Jeżeli postępowanie zgodne z Bożymi przykazaniami uznaje się za ważny czynnik w poznawaniu prawa wolności, to jednak nie wystarczy, by być doskonałym. Potrzeba jeszcze, jak mówi Marek Eremita, „Bożych darów", ${ }^{11}$ przez które możemy rozumieć dary łaski.

7 Zob. A. J a s i e w i c z, Święty Marek Mnich, O Prawie duchowym, s. 257.

8 Marek Eremita, De lege spirituali, 28, PG 65, 909, tłum. A. J a s i e w i c z, Święty Marek Mnich, s. 262.

9 Tamże, 30 (tłum. J a s i e w i c z, s. 262).

10 Tamże, 29 (tłum. J a s i e w i c z, s. 262).

11 Tamże, 31 (tłum. J a s i e w i c z, s. 262: „Kiedy przymusi nas nasze sumienie do wypełnienia wszystkich przykazań Bożych, wtedy może zrozumiemy, że prawo Boże jest bezbłędne /Ps 19, 8, LXX/ i w spełnianiu przykazań odnajdziemy nasze dobro, a one nie uczynią nas doskonałymi bez Bożych darów"). 
Nasz autor dodaje więcej. Mówi mianowicie, że „ci, którzy nie liczą się ze wszystkimi przykazaniami Chrystusa, podobni są do tych, którzy Boże prawo przyjmują na sposób cielesny, «nie rozumiejąc ani tego, co mówią, ani tego, co stanowczo twierdzą» (1Tm 1,7). W rezultacie myślą, że mogą wypełniać prawo dzięki czynom". ${ }^{12}$ Nieodzowna jest zatem łaska, która pomaga poznać i wypełniać Boże przykazania, kierując się ich duchem, nie zaś literą prawa. Takie podejście gwarantuje osiągnięcie doskonałości.

Marek Eremita mówi o wolności w jeszcze innym kontekście, mianowicie chrztu świętego. W dziele De baptismo wiele razy

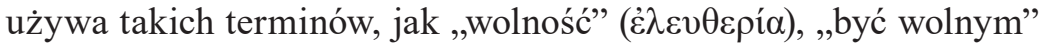

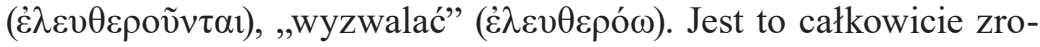
zumiałe, kiedy weźmiemy pod uwagę fakt, że nasz autor często powołuje się na św. Pawła, ten zaś w swoich wypowiedziach zaznacza, że chrzest wyzwala człowieka z niewoli grzechu i czyni go wolnym. Mnich Marek podkreśla też wyzwolenie człowieka przez Chrystusa, On bowiem przynosi mu prawdziwą wolność. Natomiast grzech zniewala nas zawsze i pozbawia mocy. ${ }^{13}$

Wymieniając konsekwencje, jakie wynikają z chrztu świętego, nasz Mnich oprócz oczyszczenia ( $\kappa \theta \theta \alpha \rho 1 \sigma \mu o ́ \varsigma)$ i zamieszkania

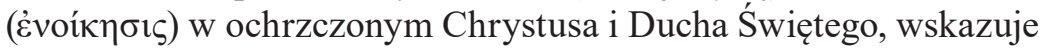
również na wyzwolenie ( $\dot{\varepsilon} \lambda \varepsilon v \theta \varepsilon \rho i ́ \alpha)$ z grzechów. Marek Eremita jest bowiem świadomy tego, że grzech pierworodny uczynił człowieka bardziej podatnym na zło niż dobro. Nie oznacza to oczywiście, zdaniem autora, fizycznego przymuszania do grzechu. ${ }^{14}$ Można jednak mówić o pewnym osłabieniu i zniewoleniu $(\delta o v \lambda \varepsilon i ́ \alpha)$ człowieka ${ }^{15}$ na skutek ,haniebnych namiętności” ( $\left.\pi \alpha \dot{\theta} \theta \eta \tau \tilde{\eta} \varsigma \dot{\alpha} \tau \mu \mu^{\prime} \alpha \varsigma\right),{ }^{16}$ jakie w nim drzemią (por. Rz 1,26). Dlatego Marek Eremita zwraca uwagę, że to

12 Tamże, 32 (tłum. J a s i e w i c z, s. 262).

13 Zob. te nże, De baptismo, V 143-146, w: Traités I, wstęp i tłum. G.-M. D e D u r a n d, Cerf, Paris 1999 (dalej: SCh 445), s. 336; tamże, IX 39, 358.

14 Zob. te n ż e, Adversus Nestorianos, 29, wyd. i tłum. G.-M. D e D u r a nd, Cerf, Paris 2000 (dalej: SCh 455), s. 284.

15 Zob. te n ż e, De baptismo, II 60, s. 304.

16 Te n ż e, Ad Nicolaum praecepta animae salutaria, IX 5, PG 65, 1041. 
właśnie chrzest przynosi wolność, uwalnia od złych mocy i dominacji zła. ${ }^{17}$ Nie oznacza to jednak całkowitej wolności od grzechu po przyjęciu chrztu. Człowiek nadal jest zagrożony napaściami ( $\pi \rho \circ \sigma \beta o \lambda \eta ́)$ ze strony diabła, ponieważ obdarzony został wolną wolą, ta zaś nieustannie jest atakowana przez szatana. ${ }^{18}$ Jest to zatem całkowicie różne podejście do chrztu od tego, jakie reprezentowali messalianie, ${ }^{19}$ którzy uważali, że po przyjęciu tego sakramentu demon ustawicznie przebywa w człowieku i ciągle go zdobywa. ${ }^{20}$

Należy również podkreślić, że według św. Marka Eremity sakrament chrztu uwalnia ochrzczonego od grzechu do tego stopnia, że umożliwia mu powrót do takiego stanu, jakim cieszył się Adam przed grzechem. Dlatego wspomina o tzw. drugim raju, przez który

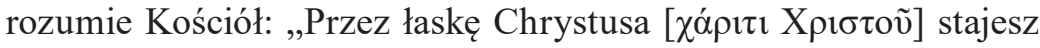
się nowym Adamem (...). Pan dla nas przyszedł i dla nas umarł; On

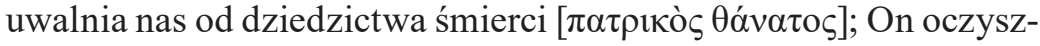
cza i odnawia nas przez chrzest; On umieszcza nas w Raju Kościoła

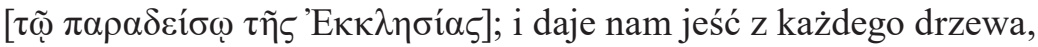
które rośnie w Raju - to jest miłość do wszystkich ochrzczonych w Kościele". ${ }^{21}$ Chrzest to nie tylko współpraca Boga i człowieka, to również posłuszeństwo ze strony człowieka duchowemu prawu i prawu wolności, o czym przekonuje św. Paweł (por. Rz 7,14).

Mnich dostrzega bliską relację chrztu z prawem wolności, mówi bowiem, że „chrzest jest doskonałością [ $\tau \varepsilon \dot{\lambda} \lambda \varepsilon ı v]$, ale nie stanie się

17 Zob. te n ż e, De baptismo, II 45, s. 302; A. J a s i e w i c z, Misterium chrztu świętego w nauczaniu ascetycznym św. Marka Mnicha, s. 209.

18 Zob. Marek Erem it a, De baptismo XI 70 - XIII, 5, s. 370-374.

19 Messalianie to sekta znana w Azji Mniejszej oraz w Grecji i Egipcie. Jej wyznawcy głosili, że na skutek grzechu Adama diabeł zamieszkał w każdej duszy. Można go wyrzucić wyłącznie przez modlitwę i prowadzenie życia ascetycznego. Więcej na temat tej sekty zob. G. O ' C o 11 i n s, E. G. F a r r u g i a, Leksykon pojęć teologicznych i kościelnych z indeksem angielsko-polskim, tłum. B. Ż a k, Kraków 2002, s. 175.

${ }^{20}$ Zob. A. J a s i e w i c z, Misterium chrztu świętego w nauczaniu ascetycznym św. Marka Mnicha, s. 210.

${ }_{21}$ Marek Eremit a, De baptismo, XVII 20, s. 388. 
doskonałym ten, kto nie wypełnia przykazań (...). Albowiem wiara nie sprowadza się tylko do bycia ochrzczonym w Chrystusie, ale także do wypełniania Jego przykazań". ${ }^{22}$ Ciągle zatem powraca u niego przekonanie, że wypełnianie przykazań staje się warunkiem otwarcia na Chrystusa, a co za tym idzie, bycia człowiekiem doskonałym.

\section{Laska}

Mówiąc o łasce, św. Marek Eremita często utożsamia ją z darem Ducha Świętego. Nazywa ją łaską Ducha Świętego, która ,jest jedna i niezmienna. «Działa zaś w każdym człowieku tak, jak chce» (1Kor 12,11)". ${ }^{23}$ Eremita zaznacza jednocześnie, że została ona podarowana człowiekowi w sakramencie chrztu świętego. Odkrywamy tutaj zatem drugi, nie mniej ważny element obecny w nauczaniu św. Marka na temat łaski, mianowicie że przekazywanie jej odbywa się w chrzcie. „Każdy - mówi święty Eremita - kto prawowiernie został ochrzczony, otrzymał w pełni sakramentalną łaskę". ${ }^{24}$

Watek odnoszący się do powiązania łaski z chrztem Marek rozwija w cytowanym już wcześniej dziele De baptismo. Pisze w nim, że: „Chrystus, (...) będąc doskonałym Bogiem dał ochrzczonemu doskonałą łaskę Ducha. Z naszej strony, nie możemy niczego dodać do tej łaski, ale odkryć ją w sobie i objawić jej działanie poprzez wypełnianie przykazań (...). Cokolwiek, po odnowieniu w sobie łaski, ofiarujemy Jemu, to zapewne było już ukryte w nas i ma swe źródło w Nim". ${ }^{25}$

Czytając tę wypowiedź św. Marka Eremity, warto zwrócić uwagę na kilka istotnych kwestii. Mówiąc o łasce otrzymywanej w chrzcie świętym, podkreśla, że posiadamy „doskonałą łaskę Ducha” ( $\tau \varepsilon \lambda \varepsilon i ́ \alpha v$

22 Tamże, II 10, s. 298.

23 Te n ż e, De his qui putant se ex operibus iustificari, 115, PG 65, 947; tłum. J. N a u m o w i c z, Filokalia. Teksty o modlitwie serca, Tyniec 1998, s. 108.

24 Tamże, 92, 944 (tłum. N a u m o w i c z, s. 107).

25 Te nż e, De baptismo, XVII 85-89, s. 396. 


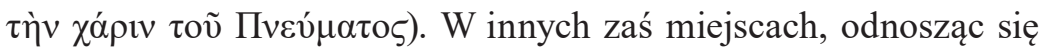
także do chrztu, wskazuje na łaskę Bożą ( bądź też na zamieszkiwanie Ducha Świętego w sercu ochrzczonego

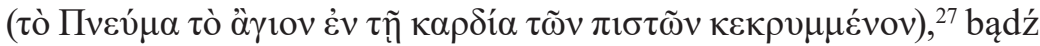

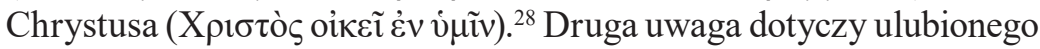
przez Marka tematu, mianowicie wypełniania przykazań. Dzięki temu chrześcijanin nie tylko odkrywa w sobie łaskę, ale przede wszystkim dostrzega jej działanie. Co więcej, łaska chrzcielna jest na tyle doskonała i wystarczająca, że żaden postęp duchowy nie jest w stanie nic do niej „dodać”. ${ }^{29}$ Wynika to, zdaniem Eremity,

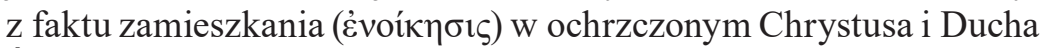
Świętego. ${ }^{30}$

Marek Eremita, mówiąc o łasce Ducha Świętego, którą otrzymujemy podczas chrztu, wyraźnie polemizuje z poglądami wspominanych już wcześniej messalian. Uważali oni, że Duch Święty nie przychodzi z chrztem, tylko na końcu życia duchowego chrześcijanina. Tymczasem autor De baptismo jest zdania, że łaska Ducha Świętego darowana jest w czasie chrztu, czyli na początku drogi chrześcijańskiej. ${ }^{31}$ Nasz Mnich sądzi, że czym innym jest posiadanie przez ochrzczonego w swoim wnętrzu Chrystusa i Ducha Świętego, czym innym zaś świadomość Ich obecności, co powinno prowadzić do wprowadzenia w czyn odkrytej łaski. Marek wyraża to w następujących słowach: ,Łaska została sakramentalnie podarowana tym, którzy są ochrzczeni w Chrystusie. Działa ona jednak w miarę wypełniania przykazań". ${ }^{32}$ Można zatem wyróżnić w tej myśli Eremity

26 Zob. tamże, II 26-37, s. 300-302.

27 Zob. tamíe, V 235, s. 344.

28 Zob. tamże, IV 93, s. 322.

29 Zob. A. J a s i e w i c z, Misterium chrztu świętego w nauczaniu ascetycznym św. Marka Mnicha, s. 208; K.T. W a r e, Baptism and the Ascetic Life in the Teaching of Mark the Monk, Studia Patristica 10/1970, s. 441-443.

30 Zob. M are k Er e m it a, De baptismo, XVII 95, s. 396.

31 Tamże, V 235, 275, s. 344, 348, zob. także A. J a s i e w i c z, Misterium chrztu świętego w nauczaniu ascetycznym św. Marka Mnicha, s. 211.

32 Mare k E remit a, De his qui putant se ex operibus iustificari, 56, 937. 
dwa poziomy. W pierwszym chodzi o łaskę chrztu ukrytą ( $\mu v \sigma \tau 1 \kappa \tilde{\omega} \varsigma)$

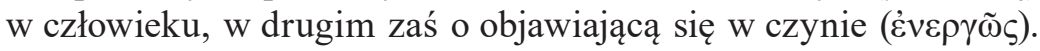
Dokonuje się to przez wypełnianie przykazań. „Każdy, kto prawowiernie został ochrzczony - mówi św. Marek Mnich - otrzymał w pełni sakramentalną łaskę. Później jednak utwierdza się w niej

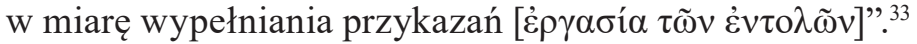

W traktacie $O$ tych, którzy sadzą, że z uczynków moga być usprawiedliwieni powołuje się na opinię niektórych, którzy mówią: „Nie możemy czynić dobra, jeśli nie otrzymamy mocy i łaski Ducha Świętego". ${ }^{34} \mathrm{Z}$ powyższych słów wynika, że tylko dzięki łasce możemy czynić dobro; należy jednak zaznaczyć, iż łaska przekazana sakramentalnie nie działa w sposób magiczny. Domaga się od nas konkretnego czynu i współpracy. Eremita mówi bowiem, że łaska

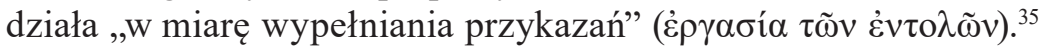
Powtarza to na innym jeszcze miejscu swojego dzieła $O$ tych, którzy sądza, że z uczynków moga być usprawiedliwieni. Mówi bowiem, że człowiek, który otrzyma sakramentalną łaskę chrztu świętego, ,później jednak utwierdza się w niej w miarę wypełniania przykazań". ${ }^{36}$ Marek Mnich jest nawet zdania, że: „Kto żąda działania Ducha Świętego, zanim wypełnił przykazania, podobny jest do niewolnika na targu, który w chwili, gdy się go nabywa, domaga się, by spisano poświadczenie zarówno jego kupna, jak i wolności". ${ }^{37}$

Nie oznacza to jednak całkowitej bierności Bożej łaski i tego, że od momentu jej otrzymania wszystko zależy wyłącznie od człowieka. Nie mamy tutaj oczywiście do czynienia z żadnym pelagianizmem, poniewaź św. Marek z całym przekonaniem mówi, że łaska „nie przestaje (...) wspierać nas w ukryty sposób. Musimy jednak czynić dobro, wedle możliwości" ${ }^{38}$

\footnotetext{
33 Tamże, 85, 944.

34 Tamże, 59, 940.

35 Tamże, 61, 940 (tłum. N a u m o w i c z, s. 106).

36 Tamże, 92, 944 (tłum. N a u m o w i c z, s. 107).

37 Tamże, 64, 940 (tłum. N a u m o w i c z, s. 107).

38 Tamże, 61, 940 (tłum. N a u m o w i c z, s. 106-107).
} 
Na czym polega owo wspieranie nas przez łaskę w ukryty sposób? Najpierw, stwierdza Eremita, łaska „budzi sumienie. Dlatego Bogu podobają się złoczyńcy, którzy się nawracają". ${ }^{39}$ Można zatem doszukać się tutaj powiązania łaski z Bożym miłosierdziem, którego nikt nie jest pozbawiony, nawet największy grzesznik. Przyjęta przez człowieka Boża łaska daje Bogu możliwość udzielania przebaczenia. Na tym jednak nie kończy się owo wspieranie nas przez łaskę w ukryty sposób. Marek dodaje bowiem, że ukryta jest ona także w „pouczeniach bliźniego" ${ }^{40}$ Tego typu stwierdzenie prowadzi do przekonania, że oddziaływanie Boga na nas dokonuje się również przez drugiego człowieka. Wysłuchanie jego wskazówek, udzielanie nam rad, można potraktować jako przejaw działania Bożej łaski.

Jest jeszcze trzeci element, na jaki wskazuje Eremita. Mówi on, że wspieranie łaski w ukryty sposób polega też na tym, iż „niekiedy towarzyszy myślom podczas lektury i, w naturalny sposób, uczy rozum swej własnej prawdy"4l. W tym przypadku można mówić o wewnętrznych natchnieniach, jakim poddawany bywa człowiek otwarty na łaskę Bożą.

Święty Marek Eremita podkreśla też, że konieczna jest współpraca człowieka z łaską Bożą: ,Jeśli tylko nie ukryjemy talentu, a więc naszego udziału w jej rozwoju, naprawdę «wejdziemy do radości Pana» (Mt 25,14-30)". ${ }^{42}$ Posługuje się przy tym czytelnym porównaniem, kiedy mówi, że „ziarno nie wzrośnie bez gleby i wody. Podobnie człowiek nie znajdzie pożytku bez podjęcia trudu i pomocy Bożej". ${ }^{43}$

Marek Eremita wyjaśnia też, po czym można poznać działanie łaski Bożej w człowieku. Są to jednocześnie praktyczne wskazówki: co należy czynić, jaką przyjąć postawę, by nieustannie żyć w łasce. Święty zachęca przede wszystkim do czujności, wytrwałości i modlitwy. Mówi bowiem: „Kto bez trudu czuwa, jest wytrwały

\footnotetext{
39 Tamże, 62, 940 (tłum. N a u m o w i c z, s. 107).

40 Tamże, 63, 940 (tłum. N a u m o w i c z, s. 107).

41 Tamże.

42 Tamże.

43 Tamże, 70, 940 (tłum. N a u m o w i c z, s. 107).
} 
i modli się, ten w widoczny sposób żyje w łasce Ducha Świętego". ${ }^{4}$ Marek, będąc świadomy ludzkiej słabości, dopuszcza jednak sytuację, w której człowiek mimo dobrej woli i wielu chęci, nie zawsze potrafi tym wymaganiom sprostać. Nie przekreśla go, ale pociesza, że „kto (...) ma z tym trudności, ale trwa w postanowieniach, szybko otrzyma pomoc". ${ }^{45}$

Święty Mnich, posługując się obrazami zaczerpniętymi z życia codziennego, zwraca również uwagę na powód, dla którego człowiek otrzymuje łaskę. Jednym $\mathrm{z}$ nich jest siła potrzebna do życia w cnotach. Mówi bowiem: „Kiedy deszcz spada na ziemię, nadaje roślinom jakość, właściwą ich naturze: słodkim - słodycz, gorzkim - gorycz. Podobnie łaska, która niezmiennie przenika serca wierzących, udziela im mocy właściwych dla cnót". ${ }^{46}$

Innym powodem otrzymywania łaski staje się potrzeba wewnętrznego rozwoju i wzrastania, ponieważ stanowi ona dla duszy ludzkiej pokarm, napój, ubranie, odpoczynek, radość i umocnienie. Eremita mówi: „Dla tego, kto jest głodny ze względu na Chrystusa, łaska staje się pokarmem, dla pragnącego - słodkim napojem, dla marznącego - odzieniem, dla trudzącego się - ulgą, dla modlącego się zaś - utwierdzeniem, dla smutnego - pocieszeniem". ${ }^{47}$

Marek Eremita przestrzega przed lekceważeniem Bożej łaski lub zapomnieniem o niej. Dlatego w Liście do mnicha Mikołaja, który jest piękną lekcją na temat tego, że cokolwiek otrzymaliśmy od Boga, jest Jego łaską, prosi: „Nie dopuść, aby zło przesłoniło ci pamięć o wielu łaskach, albo, byś o nich zapomniał przez niedbalstwo. Wówczas bowiem resztę swego życia spędzisz bez pożytku i w niewdzięczności”" ${ }^{48}$ Staje się to ważne chociażby w obliczu poczucia wdzięczności Bogu, który „dla zbawienia obdarzył mnie wieloma

44 Tamże, 98, 944 (tłum. N a u m o w i c z, s. 108).

45 Tamże.

46 Tamże, 116, 948 (tłum. N a u m o w i c z, s. 108).

47 Tamże, 117, 948 (tłum. N a u m o w i c z, s. 108).

48 Te nże, Ad Nicolaum praecepta animae salutaria, II, 1029 (tłum. $\mathrm{N}$ a u m ow ic z, s. 109). 
darami i łaskami”. ${ }^{49}$ Należy zwrócić uwagę na jeszcze jeden ważny aspekt obecny w tej wypowiedzi Marka Eremity. Mówi tutaj nie tylko o łasce, jaką otrzymujemy w sakramencie chrztu świętego, ale o wszystkich innych łaskach, które stają się udziałem człowieka.

Zachęta do trwania w każdej otrzymanej od Boga łasce powtarza się wiele razy. W cytowanym już Liście do mnicha Mikołaja św. Marek mówi do niego: „Ze względu na to, ukochany mój synu, iż przez łaskę Chrystusa z natury dane ci jest zrozumienie, zawsze strzeż w sobie owego rozmyślania i dobrego zajęcia. Nie pozwól, aby okryła cię zgubna niepamięć. Nie dopuść, aby przeszkodziła ci niedbałość, która czyni umysł bezużytecznym i odwraca go od życia". ${ }^{50}$ Mówiąc o łasce, Marek Mnich ciągle podkreśla, że należy na nią patrzeć jako na dar Boga. Dlatego powołuje się na różnego rodzaju sytuacje życiowe, które mogą nas utwierdzać w błędnym przekonaniu, że to nasza postawa sprawia, iż spełniane przez nas czyny zasługują na uznanie.

Tymczasem, jeżeli nawet darzymy kogoś życzliwością, miłością, rozmawiamy ze sobą jak bracia, czynimy wokół dobro, wszystko to jest owocem wspomagającej nas Bożej łaski: „Kiedy jeden człowiek jest dla drugiego pożyteczny w słowach lub czynach, obaj powinni rozumieć, że jest to łaska Boża. Kto tego nie rozumie, będzie opanowany przez tego, kto to rozumie". ${ }^{51}$ Święty Marek powie jeszcze więcej: „Pan, chcąc pokazać, że jesteśmy zobowiązani do przestrzegania wszystkich przykazań, ale że przyjęcie za synów jest łaską udzieloną ludziom przez wylanie Jego Krwi, rzekł: «Gdy uczynicie wszystko, co wam polecono, tak mówicie i wy: Słudzy nieużyteczni jesteśmy; wykonaliśmy to, co powinniśmy wykonać» (Łk 17,10). Królestwo niebieskie nie jest bowiem nagrodą za uczynki, ale łaską Pana, przygotowaną dla wiernych sług". ${ }^{52}$ Powraca tutaj temat chrztu,

49 Tamże, II, 1032 (tłum. N a u m o w i c z, s. 110).

50 Tamże, III, 1032 (tłum. N a u m o w i c z, s. 111).

51 Te n ż e, De lege spirituali, 76, 913 (tłum. J a s i e w i c z, s. 265).

52 Te n ż e, De his qui putant se ex operibus iustificari, 2, 929 (tłum. N a u m ow i c z, s. 105). 
usynowienia, nagrody wiecznej, czego nie otrzymujemy za nasze ludzkiej zasługi i wyłącznie za wypełnianie Bożych przykazań, lecz dzięki łasce Pana. Potrzeba, oczywiście, wierności z naszej strony, nie można jednak zapominać o podstawowej prawdzie, że wszystko sprawia „łaska Pana”.

Gdybyśmy chcieli podsumować naukę św. Marka Eremity na temat wolności i łaski, należałoby powiedzieć, że nie jest ona oryginalna w sensie dodania do niej czegoś nowego. Nie ma w niej wzniosłych i trudnych spekulacji teologicznych, raczej są to praktyczne wskazówki o charakterze duchowym, mające na celu pokazanie mnichowi, że został szczodrze obdarowany przez Boga zarówno wolnością, jak i łaską. Można z całą pewnością powiedzieć, że nasz autor wiernie przekazuje najbardziej istotne aspekty doktryny o wolności i łasce.

Wolność przynosi człowiekowi Chrystus, otrzymuje ją także w sakramencie chrztu świętego, ponieważ ten uwalnia go od ciężaru grzechu. Z kolei łaskę przedstawia nasz autor zawsze jako dar Boga dany człowiekowi. Dlatego też królestwo niebieskie jest darem, a nie nagrodą za uczynki; łaską jest też zbawienie, jakie dał nam Chrystus. Postawa wdzięczności wobec Boga winna zatem towarzyszyć człowiekowi w całym jego życiu. Nie może zapominać, że wszystko otrzymał od Stwórcy jako łaskę.

W tym miejscu warto przytoczyć słowa papieża Franciszka z jego ostatniej adhortacji apostolskiej zatytułowanej Gaudete et exsultate, które mogą stanowić swoiste podsumowanie podjętych rozważań na temat wolności i łaski w doktrynie św. Marka Eremity. Jeden z paragrafów wspomnianego papieskiego dokumentu nosi znamienity tytuł: Nowi pelagianie. Czytamy tam m. in. takie słowa: „Są też chrześcijanie, którzy starają się podążać inną drogą: polegającą na usprawiedliwieniu w oparciu o własne siły, na kulcie ludzkiej woli i własnych zdolności. Przekłada się to na egocentryczne i elitarystyczne samozadowolenie, pozbawione prawdziwej miłości. Przejawia się ono w wielu postawach, pozornie różniących się między sobą: obsesji na 
punkcie prawa, uleganiu urokowi osiągnięć społecznych i politycznych, ostentacyjnej trosce o liturgię, o doktrynę i prestiż Kościoła (...). Wiele razy, wbrew impulsom Ducha Świętego, życie Kościoła zamienia się w eksponat muzealny lub dostępny dla niewielu. Dzieje się tak, gdy niektóre grupy chrześcijańskie przywiązują nadmierną wagę do zachowywania pewnych własnych norm, zwyczajów lub stylów. W ten sposób często dochodzi do ograniczenia lub tłumienia Ewangelii, poprzez pozbawienie jej właściwej sobie urzekającej prostoty i smaku. Jest to być może subtelna forma pelagianizmu, ponieważ zdaje się podporządkować życie łaski niektórym strukturom ludzkim. Dotyczy to grup, ruchów i wspólnot. Wyjaśnia to również, dlaczego tak często zaczynając od intensywnego życia w Duchu Świętym, w końcu stają się one skamieniałe (...) lub zepsute". ${ }^{33}$

Marek Eremita to jeden z najważniejszych teoretyków życia ascetycznego w Kościele starożytnym. W swoich pismach ascetycznych podejmuje wiele tematów, m. in. uczy o wolności i łasce. Nie jest to doktryna systematyczna, ale raczej wypowiedzi porozrzucane w jego dziełach, okazjonalne, często też do siebie podobne. „Wolność”

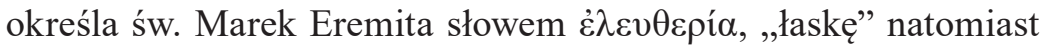
terminem $\chi \alpha$ ápıs. Wolność przynosi człowiekowi Chrystus, otrzymuje ją także w sakramencie chrztu świętego, ponieważ uwalnia go od ciężaru grzechu. Z kolei łaskę przedstawia Marek Eremita zawsze jako dar Boga dany człowiekowi. Dlatego też królestwo niebieskie jest darem, a nie nagrodą za uczynki, łaską jest też zbawienie, jakie dał nam Chrystus. Postawa wdzięczności wobec Boga winna zatem towarzyszyć człowiekowi w całym jego życiu.

ks. Bogdan CZYŻEWSKI

53 Fr a n c is z e k, Gaudete et exsultate, nr 57-58, Kraków 2018, s. 40-41. 
Słowa kluczowe: Marek Eremita; wolność; łaska; Chrystus; chrzest

Keywords: Mark the Ascetic; freedom; grace; Christ; baptism

\section{Freedom and grace in the writings of Mark the Ascetic}

\section{Summary}

Mark the Ascetic is considered as one of the most prominent theoreticians of ascetic life in the ancient Church. In his ascetic writings, he undertook a variety of topics, including freedom and grace. Mark's teaching is not a systematic doctrine. His tuitions are more a collection of short statements scattered in many places in his works. The author uses the Greek word

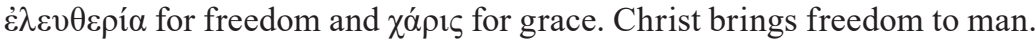
In the sacrament of baptism, man is freed from the original sin. In turn, the grace is always depicted as a gift, which man can only receive from God. Therefore, the Kingdom of God is always a gift, and neither a prize, nor a reward for work. The entire salvation is the greatest grace, which has been given to us by Christ. The attitude of gratitude to God should overfilled the entire human life. 